\title{
Die karakterisering van Natanael in die Johannesevangelie
}

NGTT DEEL 55, NR 3 \& 4, 2014

\section{Hunt, Steven A}

Universiteit van die Vrystaat

\begin{abstract}
The characterization of Nathanael in the Gospel of John

In this article the characterization of Nathanael is investigated by taking into account both historical concerns and literary aspects. After a brief discussion of questions pertaining to Nathanael's identity and historicity, his basic characterization is discussed. Following this, a number of important issues are investigated in more detail, namely the way in which the introduction of this character on the fourth day can be related to the cosmological setting in the Gospel; the suggestion that Nathanael is portrayed as a follower of the Baptist and gift of God; an exploration of the intercharacterizational relationship of Nathanael and Simon Peter; and, finally, an investigation of the intertextual relationships between the Nathanael episode and Zechariah 3:10 (in particular, the notions of the "Branch" and "under the fig tree").
\end{abstract}

\section{TREFWOORDE}

Johannesevangelie, Karakter-analise, Natanael, Inter-karakteriële analise, Intertekstualiteit

KEYWORDS

Gospel of John, Analysis of characters, Nathanael, Intercharacterizational analysis, Intertextuality

\section{KONTAKBESONDERHEDE}

Prof Steven Hunt

Fakulteit Teologie, Universiteit van die Vrystaat

Posbus 339, Bloemfontein, Suid-Afrika, 9300

Steve.Hunt@gordon.edu 


\section{INLEIDING}

Die afgelope tyd is daar al hoe meer Johanneïse navorsers wat worstel met die vraag of dit nie dalk wenslik is om 'n breër aanpak te volg wanneer 'n mens die Johannesevangelie vanuit narratiewe perspektief ondersoek nie. ${ }^{1}$ In hierdie artikel word by hierdie tendens aangesluit en word' $n$ eie analise van een van die interessante karakters in die Johannesevangelie gedoen, maar dan met 'n breër aanpak as wat normaalweg gevolg word. Wanneer karakter-analises soos die een in hierdie artikel gedoen word, is navorsers geneig om te fokus op aspekte soos die identiteit van die karakter en die basiese manier waarop die karakterisering in die teks plaasvind. Dit word ook in hierdie artikel gedoen (afdelings 2 en 3), maar daarna word doelbewus gepoog om breër oor die karakterisering van Natanael te dink. Dit word gedoen deur ook ander belangrike fasette van die karakterisering van hierdie karakter te ondersoek wat tot dusver nog nie aandag gekry het nie, naamlik hoe Natanael as karakter gebruik word om aan belangrike temas in die Johannesevangelie gestalte te gee, hoe sy rol reliëf kry as 'n mens dit deur middel van "inter-karakteriële" analise ontleed, en watter nuwe perspektiewe na vore tree as 'n mens die manier hoe hy uitgebeeld word, intertekstueel ontgin. Hierdie aspekte kry in afdelings 4 tot 7 aandag.

\section{NATANAEL: IDENTITEIT EN HISTORISITEIT}

Natanael kom nie in die lyste van die twaalf dissipels in die Sinoptiese Evangelies voor nie; net in die Johannesevangelie, waar hy slegs twee keer genoem word: in Johannes 1:45-51 en 21:2. Daar is al verskeie pogings aangewend om hom met een van die dissipels in die Sinoptiese Evangelies te identifiseer, met Bartolomeus (bv Holzmeister, 1940:28-39), Matteus (bv Hanhart, 1970:22-46) en Jakobus van Alfeus (bv Hill, 1997:45-61) wat die gunstelinge blyk te wees. Sulke pogings moet egter met 'n knippie sout geneem word, want in die Johannesevangelie staan die Twaalf glad nie voorop nie. Hulle word vir die eerste keer in Johannes 6:67 genoem, omtrent 'n jaar ná die Natanael-episode (uitgedruk in terme van narratiewe teks-tyd), en dit wil oor die algemeen voorkom of die groter dissipelgroep in die Johannesevangelie meer aandag kry as die Twaalf.

Ten opsigte van die vraag na die historisiteit van Natanael is daar party NuweTestamentici wat baie maak van die feit dat daar in die Talmoed verwys word na 'n sekere "Netzer" wat een van Jesus se dissipels was (b. Sanhedrin 43a) en

1 Kyk byvoorbeeld die bydraes van verskeie outeurs in Thatcher \& Moore (2008) hieroor; Bennema (2009:375-421) wat 'n metodologie vir 'n "historiese narratiewe kritiek" voorstel, asook Schnelle (2001:352-359). 
die moontlikheid dat hierdie naam 'n sinspeling op "Nittai" is wat met Natanael in verband gebring kan word. Op grond hiervan word dan aanvaar dat Natanael werklik een van Jesus se dissipels was en nie bloot 'n fiktiewe figuur is nie. ${ }^{2}$ Vir die doeleindes van hierdie artikel word hierdie moontlikheid egter nie verder ondersoek nie.

\section{DIE BASIESE KARAKTERISERING VAN NATANAEL}

In narratologiese terme is Natanael 'n "plat" karakter ${ }^{3}$ wat 'n positiewe reaksie op Jesus verteenwoordig. Die karaktertrekke wat met dié karakter geassosieer word, word vervolgens bespreek:

Aan die einde van die Evangelie meld die verteller dat Natanael van Kana in Galilea afkomstig is (21:2; vgl. ook 2:1-11; 4:46-54). Lesers sou dus uit die feit dat hy in hoofstuk 1 op die toneel verskyn, kon aflei dat hy ver van die huis af is, en op een of ander manier te doen gehad het met die bediening van Johannes die Doper in die Jordaangebied (later meer hieroor). Op grond van Filippus se uitnodiging in 1:45 en die feit dat Natanael onder 'n vyeboom gesitueer word - die tradisionele plek vir die bestudering van die Skrif (sien byvoorbeeld Koester, 1990:31) - argumenteer navorsers gewoonlik dat hy as 'n ernstige ondersoeker van die Skrif uitgebeeld word (bv Schnackenburg, 1968-82:1.315, 317). Natanael se aanvanklike reaksie op Filippus se uitnodiging ("Kan daar uit Nasaret iets goeds kom?") verwoord onsekerheid, ${ }^{4}$ maar sit spoedig om in positiewe aksie as hy saamgaan na Jesus toe. Filippus se uitnodiging is op die wet gebaseer, en dit is opvallend dat Natanael se eerste reaksie nie is om self ook terug te gryp na die wet nie - soos wat die "Jode" gewoonlik doen nie (sien bv Joh 5:39 en 7:52), wat hierdie karakter onmiddellik in 'n ander kategorie as hulle plaas. Dat Natanael na Jesus gaan, moet dus as positief geïnterpreteer word, veral in die lig daarvan dat dissipelskap in die Johannesevangelie baie nou geassosieer word met die navolging van Jesus en by Hom wees/bly.

2 Kyk byvoorbeeld Bauckham (2007:168-169.)

3 Vir die onderskeid tussen "plat" en "ronde" karakters, kyk Forster (1927:54-84). Volgens Forster was 'n "plat" karakter 'n karakter wat nie die leser op enige manier verras nie. Mettertyd is die begrip "plat" karakters egter al hoe meer gebruik om karakters aan te dui wat nie uitvoerig gekarakteriseer word nie. Dit is op laasgenoemde manier dat hierdie begrip in hierdie artikel gebruik word.

4 Brown (1966-70:1.86) beskryf Natanael se antwoord as "disparaging", Barrett (1978:184) noem dit "scornful” en Duke (1985:54) gebruik die woord "cynical”, maar sulke interpretasies lyk onnodig negatief. 
Dat Jesus se karakterisering van Natanael (1:47: “... 'n ware Israeliet in wie daar geen bedrog is nie") korrek is, blyk sommer dadelik uit Natanael se reaksie op Jesus se woorde as hy vra waarvandaan Jesus hom ken (1:48a). Dit is 'n opregte reaksie, sonder enige geveinsde nederigheid of onnodige onderdanigheid. Jesus se antwoord aan hom (1:48b: "Voordat Filippus jou geroep het, toe jy onder die vyeboom was, het Ek jou gesien") openbaar Jesus se bo-natuurlike kennis, waarop Natanael nie net met verwondering reageer nie, maar ook met 'n buitengewone belydenis van geloof (1:49: "Rabbi, U is die Seun van God, $U$ is die Koning van Israel"). Culpepper (1983:23) skryf tereg hieroor: "Nathanael is in every respect the model Israelite, John's designation for the true or faithful Jew."

Alhoewel Natanael dus op 'n positiewe manier in die Evangelie uitgebeeld word, bly hy 'n "plat" karakter. Daar is geen ontwikkeling in sy karakterisering nie, en die leser kry ook nie toegang tot sy innerlike ervaring nie. Sy belydenis oor Jesus mag dalk die leser verras, maar nie omdat dit in stryd is met sy karakter nie. Hy bly dus 'n "plat karakter", of in Bennema (2009:68) se woorde 'n “tipe", nie 'n individu nie.

Wanneer 'n mens die karakterisering van Natanael uit ander hoeke bekyk, is daar egter nog veel meer om te ontdek as dit wat tot sover uitgelig is. Hoe 'n mens te werk kan gaan om dit te doen, word nou in die volgende afdelings geillustreer. Daar word eerstens gekyk na die wyse waarop die karakterisering van Natanael in verband gebring kan word met die belangrike rol wat die skeppingstema in die Johannesevangelie speel.

\section{DIE SKEPPINGSTEMA IN DIE JOHANNESEVANGELIE EN NATANAEL SE VERSKYNING OP DIE VIERDE DAG}

Dat die skepping 'n belangrike tema in die Johannesevangelie speel, is al telkens aangetoon. Ek lig enkele aspekte uit: Reeds in die eerste verse van die Proloog word op Genesis 1:1 gesinspeel. Verder word die eerste toneel in die Evangelie by 'n rivier gesitueer (Joh 1:28; vgl. Gen 2:10) en is daar in die tydsaanduidings in die eerste twee hoofstukke'n sinspeling op die eerste skeppingsweek (1:29, 35, 43; 2:1; vgl Gen 1:32:3). Aan die einde van die Evangelie vind 'n mens weer 'n "lydensweek" (12:1), met verskeie detailaspekte wat aan die skeppingsmotief herinner: Jesus word in 'n tuin gearresteer (18:1-12; vgl Gen 2:8 - volledig bespreek deur Zimmermann 2008:221-

5 Sien Keener (2003:1.496-498) vir 'n goeie oorsig van die navorsing wat reeds hieroor gedoen is. Die feit dat hierdie reeks van dae aan die skeppingsdae in Genesis herinner, sluit natuurlik nie uit dat dit ook 'n ander betekenis in die Evangelie mag hê nie. Sien byvoorbeeld Koester (1995:25-27) vir 'n goeie bespreking van die polisemiese aard van simbole in die Johannesevangelie. 
235), Jesus word in die "middel" gekruisig ( $\mu \varepsilon \dot{\sigma o \varsigma}$; vgl. LXX Gen 2:9), en word in 'n nuwe tuingraf begrawe (19:41; vgl. Gen 3:23-24). Verder word daar spesifiek vermeld dat Jesus op die eerste dag van die week opgewek is (20:1, 19; vgl. Gen. 1:5) en verkeerdelik vir 'n tuinier aangesien is (20:15; vgl. Gen 2:8-9, 15). Hierbenewens is die oorheersende motief in die uitbeelding van die Gees in hierdie deel van die

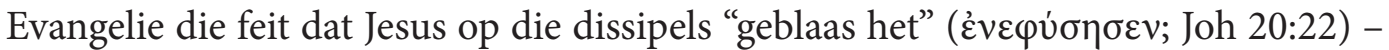
wat 'n doelbewuste teruggrype is na die moment in die skeppingsverhaal toe God

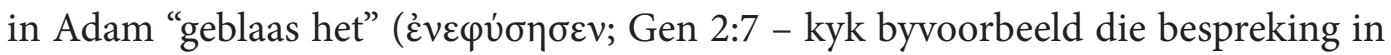
Burge 1987).

Is daar enige verband tussen die skeppingstema in die Johannesevangelie en die karakterisering van Natanael? Wel, in die Johannesevangelie verskyn Natanael $o p$ die vierde dag op die toneel. In die lig van die duidelike verwysings na die skepping in die Evangelie is dit moontlik dat hierdie tydsaanduiding van belang mag wees. Dit is belangrik dat eksegete van hierdie moment bewus moet wees; en moet weet hoe 'n mens hierdie aspek vanuit ' $n$ lees-respons-benadering kan benader. In Genesis word die vierde dag verbind aan die skepping van die son, maan en sterre wat skeiding moet maak "tussen dag en nag" (Gen 1:14) en "tussen lig en duister" (Gen 1:18). Die kontras tussen lig en duister speel 'n baie belangrike rol in die Johannesevangelie, tot so 'n mate dat Koester (1995:141) argumenteer dat “... images of light and darkness pervade the Fourth Gospel, creating what is probably its most striking motif." Dat die gebeure rondom Natanael juis op die vierde dag afspeel, kan moontlik by hierdie motief aansluit: Vir Natanael breek die lig deur oor wie Jesus is - juis op die vierde dag! In dié verband is dit ook belangrik om raak te sien hoe baie "sig"-woorde die verteller in hierdie episode gebruik: die werkwoord ópáw ("sien") kom ses keer voor; ¡ $\delta \varepsilon$ ("kyk") een keer; en die semanties-verwante begrip zípí $\sigma \kappa \omega$ ("vind) twee keer. Op hierdie manier word die skeppingstema en die gedagte dat Jesus se heerlikheid gesien sal word (wat albei reeds in die Proloog aangeroer is; Joh 1:1-5 en 1:14) 'n werklikheid in die karakterisering van Natanael.

Daar is nog twee verdere aspekte wat in hierdie verband uitgelig moet word:

Let op dat die taak van die hemelliggame volgens Genesis 1:14-19 sou wees om lig

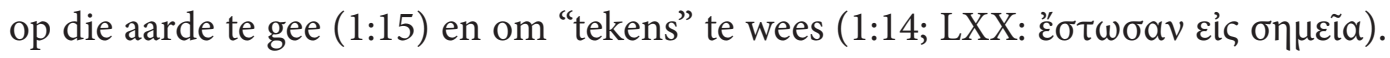
In die Johannesevangelie is Jesus die Lig vir die wêreld (Joh 8:12), en dit mag dus van belang wees dat in die episode wat direk op die Natanael-episode volg - die

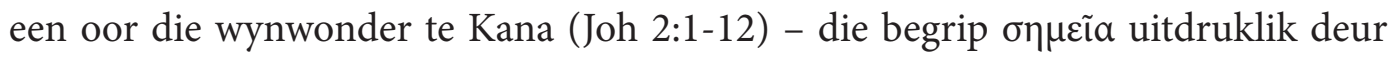
die verteller beklemtoon word (Joh 2:11). Dat Natanael van Kana afkomstig is, en die wynwonder in Kana afspeel, versterk die band tussen hierdie twee episodes verder. Natanael is een van die dissipels wat die onthaal saam met Jesus bywoon, sy heerlikheid sien en in Hom glo (aldus die vertellerskommentaar in Joh 2:11). Die 
wynwonder in Kana is dus al reeds 'n eerste direkte vervulling van die belofte wat Jesus aan Natanael gemaak het dat hy nog "groter dinge" sal sien (Joh 1:50).

Verder mag dit ook belangrik wees dat God - volgens Genesis - die hemelligte geskep het om oor die dag en nag te regeer (Gen 1:18; LXX: ä $\rho \chi \varepsilon เ v)$, want die begrip "regeer" wat hier gebruik word, sluit aan by 'n ander bekende tema in die Johannesevangelie, naamlik dat Jesus gekom het om die "regeerder van die wêreld" (Joh 16:11; ó ö $\rho \chi \omega v$

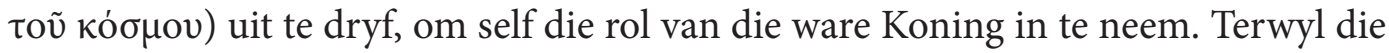
getuienis van die Doper (Joh 1:20-36) en van Andreas (Joh 1:49) alreeds op Jesus se koninklike rol sinspeel, fokus Natanael se belydenis op die vierde dag spesifiek op Jesus se koningskap, want hy bely: "U is die Koning van Israel!" (Joh 1:50).

\section{NATANAEL, VAN KANA, 'n VOLGELING VAN DIE DOPER EN'n GAWE VAN GOD}

In hierdie afdeling word dieper gedelf in twee ander aspekte wat moontlik belangrik kan wees vir die verstaan van die karakterisering van Natanael, naamlik die suggestie in die teks dat hy oorspronklik 'n dissipel van Johannes die Doper kon gewees het, asook die betekenis van sy naam.

Wat die eerste aspek betref: In die verhaal oor die roeping van die dissipels in Joh 1:19-51 is daar heelwat gapings wat deur die leser gevul moet word. Een van die boeiendste hiervan is die moontlikheid dat die dissipels wat in Johannes 1 genoem word, oorspronklik almal volgelinge van Johannes die Doper was. Dat Jesus besluit om na Galilea te gaan en dan vir Filippus roep (Joh 1:43) wat van Betsaida afkomstig was, beteken nie noodwendig dat Jesus hom daar gevind het nie. Dit beteken ook nie dat Filippus vir Natanael daar gekry het nie (so tereg Schnackenburg 196882:1.314). 'n Meer waarskynlike scenario van die gebeure is dat Jesus (met Andreas, 'n onbekende dissipel en Simon Petrus by Hom) besluit om na Galilea terug te keer, en dan onderweg nog 'n dissipel van Johannes die Doper "vind" (later meer hieroor), naamlik Filippus, wat op sy beurt weer vir Natanael "vind" wat ook 'n dissipel van Johannes die Doper was. Die hele episode versinnebeeld dus die gedagte dat Jesus "meer word" terwyl die Doper "minder word" (Joh 3:30). Hierdie groep volg dan vir Jesus na Galilea waarna die leser hulle dan in Johannes 2:1 in Galilea aantref. As 'n mens so 'n relasie tussen Jesus se dissipels en die Doper veronderstel, en in ag neem dat Jesus (in 'n sekere opsig) van Nasaret afkomstig was (Joh 1:45), asook dat Andreas, Petrus en Filippus almal van Betsaida afkomstig was, suggereer dit dat daar 'n kritiese ingesteldheid teenoor die tempel en die heersende orde by hierdie groep was. Hierdie gedagte vind ook aansluiting by een van die belangrike temas in die Johannesevangelie, naamlik dat Jesus die tempel vervang (volledig uitgewerk 
deur Coloe 2001). Aangesien Natanael ook van 'n dorp in Galilea afkomstig is, kan 'n mens aanvaar dat hy ook die negatiewe sentiment teenoor die heersende orde in Jerusalem kon gedeel het. Self verwoord hy nie hierdie negatiewe sentiment nie, maar ander dissipels doen dit wel later in die Evangelie (Joh 11:16; 18:10). Dat Natanael uit Galilea afkomstig was, kan dalk ook verklaar hoekom hy aanvanklik skepties was oor die feit dat Jesus van Nasaret die Een kan wees waaroor Moses en die profete geskryf het (Joh 1:46). Soos wat Michaels (2010:129) dit stel: "Nathanael's skepticism [arises] ... out of a stubborn provincialism in reverse that refuses to see anything great or glorious in that which is familiar or close to home."

Die tweede aspek is die betekenis van Natanael se naam. In Hebreeus beteken Natanael "gawe van God". Aangesien die verteller reeds drie keer in die vorige episode Hebreeuse woorde vertaal het (Joh 1:38, 41 en 42), mag dit 'n aanduiding aan die leser wees dat die betekenis van die Hebreeuse name deurgaans belangrik is. In hierdie geval kan dit dan beteken dat Natanael se naam daarop sinspeel dat hy een van die dissipels is wat aan Jesus "gegee" is - nog een van die belangrike temas in die Johannesevangelie, soos wat 'n mens onder andere uit Johannes 18:8-9 en 19:2627 kan aflei. Binne die Natanael-episode spesifiek verteenwoordig Natanael dié dissipels (let daarop dat die meervoudvorm "julle" in 1:51 gebruik word) wat'n gawe van God sal ontvang, naamlik 'n gesig van die Seun van die Mens in 'n geopende hemel - waarvan iets al in vervulling gaan in die volgende episode wanneer Jesus se heerlikheid aan die dissipels openbaar (Joh 2:11).

\section{DIE ROEPING VAN NATANAEL (EN VAN ANDREAS, SIMON PETRUS EN FILIPPUS)}

In hierdie afdeling word op 'n verdere faset van die karakterisering van Natanael gefokus, naamlik die wyse waarop wat 'n mens “inter-karakteriële" karakterisering kan noem, gebruik word om hom uit te beeld. Met "inter-karakteriële” karakterisering word die wyse waarop hy in terme van ander karakters in die Evangelie gekarakteriseer word, bedoel.

Soos reeds vroeër genoem is, speel die begrip "vind" 'n belangrike rol In die roepingsverhale in Johannes 1 . Andreas "vind" sy broer Simon, aan wie hy sê dat hulle die Messias "gevind" het (1:41-42). Op die tweede dag gebeur dieselfde: Jesus "vind" Filippus wat op sy beurt vir Natanael "vind" aan wie hy sê dat hulle dié Een "gevind" het waaroor die wet en profete skryf. Dié gebeure kan as volg opgesom word: 


\section{Dag 1:}

A - Jesus vind Andreas

B - Andreas "vind" vir Simon, en sê aan hom: "Ons het gevind ..."

C - Andreas bring vir Simon na Jesus

D - Jesus praat met Simon

\section{Dag 2:}

A - Jesus "vind" vir Filippus

B - Filippus "vind" vir Natanael, en sê: "Ons het gevind ..."

C - Natanael gaan na Jesus

D - Jesus praat met Natanael

Let op dat hierdie netjiese patroon by item $\mathrm{C}$ verbreek word omdat die reaksie van Simon Petrus en Natanael verskil. Op Dag 1 neem Andreas vir Petrus na Jesus toe, terwyl Natanael op Dag 2 self na Jesus toe gaan. In terme van die perspektief van inter-karakteriële analise moet hier dus uitgewys word dat Petrus se optrede hier met dié van Natanael gekontrasteer word, en dat, Petrus - soos dikwels in die Evangelie gebeur - glad nie goed vertoon wanneer hy met 'n ander karakter gekontrasteer word nie. ${ }^{6}$ Daar is drie aspekte wat hier verdere aandag verdien:

Eerstens bly Petrus heeltemal passief in Johannes 1:41-42: hy sê niks en doen niks. Die klem val volledig op Jesus en wat Hy vir Petrus sê, en Petrus verdwyn omtrent onmiddellik weer van die toneel af. Daarteenoor is Natanael as't ware die "medester" in die episode waarin hy optree. Hy reageer deur woord en daad; hy word nie na Jesus geneem nie, maar gaan self na Hom toe. En - belangrik! - dit is juis die feit dat hy na Jesus gaan wat maak dat Jesus hom identifiseer as 'n "ware Israeliet". By Jesus gekom, vra hy eers 'n vraag, en maak daarna 'n aangrypende belydenis oor wie Jesus is. Dat hy ook in Jesus glo, word geïmpliseer deur Jesus se vraag: "Glo jy omdat ...?" (so tereg Barrett 1984:186). Natanael is dus die eerste dissipel in die Evangelie wat tot geloof in Jesus kom. Anders as Petrus, is dit Natanael wat hierdie hoogtepunt in hoofstuk 1 bereik.

Tweedens, in Johannes 1:47 word gesê dat Jesus vir Natanael na Hom toe sien aankom het. Afgesien daarvan dat Natanael hier op 'n voorbeeldige wyse optree

6 Meer volledig uitgewerk deur Nicklas (2000:194-195). Vir 'n bespreking van die manier waarop Petrus met ander karakters soos die Geliefde Dissipel en Nikodemus gekontrasteer word, sien Brown (1979:82-83) en Brodie (1993:169) onderskeidelik. 
(dissipels "volg" vir Jesus en gaan na Hom toe) en dat sy aksie in kontras staan met die passiwiteit van Petrus, herinner Natanael se beweging na Jesus aan Jesus se eie beweging na die Doper toe waarvan daar in Johannes 1:29 gepraat word (vgl ook Joh 1:36). In beide gevalle word hulle raakgesien terwyl hulle nader kom, en volg daar' $n$ aankondiging, ingelui deur'I $\delta \varepsilon$ : “Kyk, die Lam van God!” en "Kyk, 'n ware Israeliet!" Vanuit inter-karakteriële perspektief gestel: vir die karakterisering van Natanael is dit belangrik om raak te sien dat hy hier op dieselfde manier as die Protagonis gekarakteriseer word, wat beteken dat hy baie positief geëvalueer word.

Derdens, wanneer Jesus na Natanael verwys as iemand sonder bedrog (Joh 1:47), sou die lesers van destyds waarskynlik sinspelings op die Jakob-verhaal in Genesis gehoor het (so tereg Brown, 1966-70:1.87). Nie alleen gryp die gebruik van die woord "Israeliet" terug na die Jakob-verhaal nie (Gen 32:28), maar herinner die

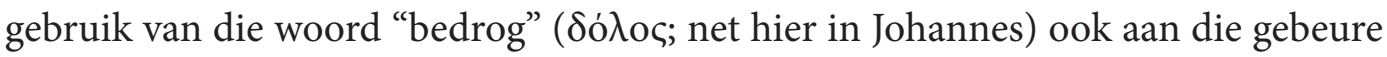

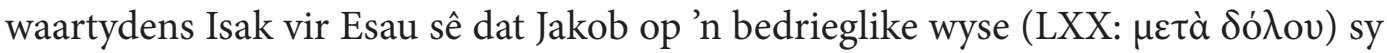
seën by hom afgevat het (Gen 27:35; vgl. ook Gen 34:13). In die Johannesevangelie word Natanael se optrede dus met die van Jakob gekontrasteer. Anders as Jakob, is Natanael 'n Israeliet sonder bedrog; en, anders as Jakob, is dit nie nodig dat Natanael se naam verander moet word nie. Simon Petrus se naam word egter wel verander. Dit is opvallend dat dit gebeur in hierdie konteks waarin Petrus met Natanael - die "anti-Jakob" - gekontrasteer word. Soos Bruce (1983:60) tereg opmerk: "Nathanael is one who is all Israel and no Jacob." Dat Petrus se nuwe naam deur die verteller geïnterpreteer word, is ook opvallend as 'n mens in ag neem dat Jakob se nuwe naam, "Israel", ook in Genesis 32:28 geïnterpreteer word. 'n Laaste aspek wat uitgelig moet word: Nadat Jakob se naam in Genesis 32 verander is, noem hy die plek Pniël omdat hy God daar gesien het (Gen 32:30). In die Proloog lees 'n mens ook van 'n "sien" van God as daar in Johannes 1:18 gesê word dat niemand God gesien het nie, maar dat die Seun Hom bekend gemaak het. Jesus se belofte aan Natanael dat hy groter dinge sal "sien" antisipeer nie net die volheid van dit wat nog oor Jesus geopenbaar sal word nie; dit versterk die kontras tussen Natanael en Petrus verder aangesien hy nie so 'n belofte van Jesus ontvang nie.

\section{NASARET, DIE “SPRUIT” EN NATANAEL ONDER 'n VYEBOOM}

Teen die einde van die vorige afdeling is reeds gewys op enkele intertekstuele aspekte wat 'n rol kon gespeel het in die karakterisering van Natanael. In hierdie afdeling word 'n verdere intertekstuele moment ondersoek, naamlik die rol wat die verwysing na Nasaret in die karakterisering van Natanael speel. Daar is reeds vroeër in hierdie artikel na Natanael se vraag of daar iets goeds uit Nasaret kan kom, verwys. Hierdie aspek sal nou intertekstueel ondersoek word. 
Eerstens is dit belangrik om daarop te let dat Natanael se vraag aansluit by die debat wat in die Evangelie oor Jesus se herkoms gevoer word (kyk bv Joh 6:41-42; 7:27-29; 8:14). Terwyl Natanael sy bedenking uitspreek - nie soseer oor die moontlikheid dat Jesus die Een is waarvan in die wet en profete gepraat word nie, maar of so 'n belangrike persoon uit Nasaret kan kom - gaan Jesus se opponente gewoonlik 'n stap verder: Hulle weier om te aanvaar dat Jesus die Een is waarop hulle gewag het, juis omdat hulle verkeerdelik aanvaar dat Hy van Galilea afkomstig is (Joh 7:41, 52) of dan spesifiek van Nasaret (Joh 18:5, 7; 19:19). Hulle aanvaar nie dat sy ware oorsprong "van bo" af is nie (Joh 3:31).

Tweedens is dit belangrik om daarop te let dat Natanael se vraag die woord "Nasaret" herhaal. Die woord "Nasaret" kom twee maal in 1:44-45 voor: eers in Filippus se woorde aan Natanael, en daarna in Natanael se reaksie op Filippus se mededeling aan hom. Hiermee saam is dit belangrik om daarop te let dat Natanael vir Jesus as "Seun van God" en "Koning van Israel" beskryf (Joh 1:49), en dat daar ook twee keer in hierdie gedeelte vermeld word dat Natanael "onder die vyeboom" gesit het voordat hy na Jesus gekom het (Joh 1:48, 50). Myns insiens sluit al hierdie aspekte bymekaar aan en funksioneer dit gesamentlik as 'n voorbereiding vir 'n belangrike moment wat later in die Evangelie voorkom. Dit word vervolgens beredeneer. Ons begin by die begrip "Nasaret".

Mary Coloe (2007:843) het reeds daarop gewys dat argeologiese opgrawings getoon het dat die woord "Nasaret" oorspronklik gevorm is van die woord netzer wat gebruik is om die toekomstige koninklike "spruit" van die Dawidshuis te beskryf. Op grond van tekste waarin dié "spruit" beskryf word, byvoorbeeld in Jesaja, Sagaria, Qumrantekste en die Targumim, argumenteer sy dan dat die term "Nasarener" in die Johannesevangelie nie funksioneer as 'n begrip wat van 'n plek afgelei is nie, maar dat dit 'n titel is wat tot Jesus se inhegtenisname en teregstelling lei (Coloe, 2007:846). Sy wys ook daarop dat dit slegs in die Johannesevangelie is dat die woord

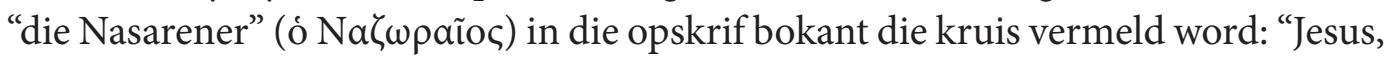
die Nasarener, die Koning van die Jode." In die lig van Joodse verwagtinge maak sy dan die volgende gevolgtrekking: "The title 'nazarene' above the head of Jesus is a reference to his messianic role as builder of the eschatological temple." (Coloe, 2007:846.) Ek wil hierdie argument van Cloe 'n entjie verder neem deur die ironiese moment in Pilatus se optrede aan te toon: In die opskrif wat hy laat skryf, verwoord hy - onwetend! - die waarheid oor Jesus: "Jesus [is] die 'Spruit', die Koning van die Jode."

Wat het dit alles met die uitbeelding van Natanael en die verhaal in Johannes 1:4551 te doen? Eerstens, in die lig van die betekenis van die begrip "Nasarener" (soos hierbo uitgewys), is die feit dat die woord "Nasaret" tweemaal in die Natanael- 
episode voorkom (in Joh 1:45 en 46) uiters belangrik aangesien dit die eerste van twee episodes is waarin voorberei word vir die latere gebruik van die titel "Nasarener" in Johannes 19:19.7 In albei hierdie episodes is Jesus se koningskap die fokuspunt. In die geval van die Natanael-verhaal kom dit eksplisiet na vore wanneer Natanael Jesus as "Koning van Israel" bely. In die tweede episode - wanneer Jesus in hegtenis geneem word - word Jesus ook twee keer "die Nasarener" genoem (Joh 18:5, 7). Met ander woorde, die woorde "Nasaret" en "Nasarener" word net in twee episodes in die Johannesevangelie gebruik waarna dit eers weer in Johannes 19:19 gebruik word. In albei hierdie episodes word die woorde herhaal - waardeur dit klem kry en die fokus baie sterk op Jesus se koningskap val. Wanneer Jesus dan later in die opskrif in Johannes 19:19 beskryf word as sowel "Nasarener" (d.w.s., die "spruit" van Joodse verwagtinge) as die "Koning van die Jode" (dws die ware Bouer van die tempel; aldus Chloe) bereik hierdie Johanneïse motief dus 'n hoogtepunt.

Dat Natanael in die eerste episode juis onder die vyeboom gesitueer word, versterk hierdie argument. Verskeie Bybelse en Rabbynse parallelle vir hierdie situering word gereeld deur navorsers uitgewys. ${ }^{8}$ Waarop ek egter die aandag wil vestig, is die afwisseling in die beskrywing in die Natanael-episode:

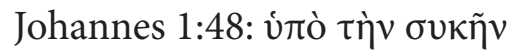

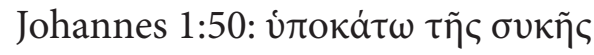

Soos Robert Alter (1981:97-113) aangetoon het, funksioneer afwisseling in herhaling

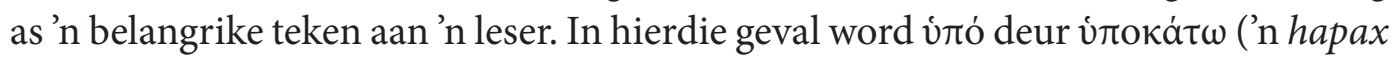
in die Johannesevangelie) vervang. Hoekom? Daar is twee parallelle hiervoor in die

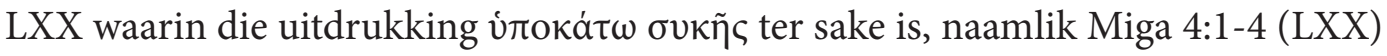
en Sagaria 3:10. Hiervan is Sagaria 3:10 die interessantste omdat daar in dieselfde konteks van die Dienaar van die Here gepraat word en hy ook "Spruit" genoem word. Verder word daar ook gesê dat die Here die skuld van die land binne 'n enkele

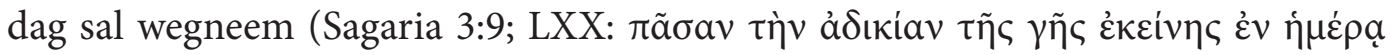
$\mu(\underline{a})$. Dat hierdie "Spruit" later in Sagaria beskryf word as die Een wat die tempel van die Here sal opbou (Sag 6:12) ondersteun die verbande wat hier gelê word verder.

Om saam te vat: vanuit intertekstuele perspektief is die feit dat Natanael twee keer met Nasaret in verband gebring word, die feit dat daar twee keer vermeld word dat hy onder die vyeboom gesit het, en die eksplisiete fokus op die koningskapsmotief in Johannes 1:41-51 belangrik. Intertekstueel gelees herinner die situering van Natanael

7 Die tweede episode is die gevangenisneming van Jesus in Johannes 18.

8 Kyk byvoorbeeld Koester (1990:23-34), Moule (1954:210-211) en Nicklas (2000:200) se bespreking van hierdie aspek. 
aan Sagaria 3 waar die Dienaar van die Here as die "Spruit" uitgebeeld word, wat op sy beurt weer met Nasaret in verband gebring kan word. Ten opsigte van die karakterisering van Natanael kan dus geargumenteer word dat die verteller van die Johannesevangelie Natanael as karakter aanwend om belangrike koningskap- en tempelmotiewe aan die begin van die Evangelie in te lui - motiewe wat later by die kruisiging van Jesus 'n hoogtepunt bereik.

\section{SAMEVATTING}

In hierdie artikel is die karakterisering van Natanael in die Johannesevangelie ondersoek. Soos aan die begin aangedui, was die bedoeling van hierdie artikel om meer te doen as wat normaalweg in die analise van karakters in die Johannesevangelie gedoen word. Die volgende nuwe fasette is dus ondersoek: Eerstens is daar 'n verband getrek tussen die situering van die Natanael-episode en die skeppingstema in die Johannesevangelie. Daar is aangevoer dat die "vierde dag" herinner aan die vierde skeppingsdag - die dag waarop die hemelligte geskep is wat die taak gehad het om lig te maak. Hierdie aspek is in verband gebring met die karakterisering van Natanael: In die verhaalgang van die Evangelie "sien" hy op die vierde dag die "Lig", is hy die eerste dissipel in die Evangelie wat tot geloof kom, en ontvang hy ook 'n belofte van Jesus dat hy (en die ander dissipels) nog baie meer sal "sien". Tweedens is twee suggesties in die teks verder ondersoek en uitgewerk, naamlik dat Natanael as 'n vroeëre dissipel van Johannes die Doper uitgebeeld word en dat sy naam "gawe" beteken - iets wat moontlik kan aansluit by die gedagte dat die dissipels aan Jesus "gegee" is, en dat hulle self ook'n gawe sal ontvang, naamlik 'n volledige openbaring van die Seun van die mens. Derdens is daar van inter-karakteriële analise gebruik gemaak, en is die kontras in die karakterisering van Natanael en Simon Petrus uitgelig en aangetoon dat Natanael (anders as Simon Petrus) op 'n baie positiewe manier uitgebeeld word. Laastens is intertekstuele aspekte verder ondersoek, en dan spesifiek die situering van Natanael onder die vyeboom wat intertekstueel met Sagaria 3:10 in verband gebring is, en op grond waarvan daar aangevoer is dat Natanael deur die verteller gebruik word om reeds vroeg in die Evangelie belangrike koningskap- en tempelmotiewe aan te voor.

\section{BIBLIOGRAFIE}

Alter, R 1981. The art of Biblical narrative. London/Sydney: George Allen \& Unwin.

Barrett, CK 1978. The Gospel according to St John. An introduction with commentary and notes on the Greek text. London: SPCK. 
Barrett, CK 1984. A commentary on the Epistle to the Romans. London: Adam \& Charles. BNTC.

Bauckham, R 2007. The testimony of the Beloved Disciple: Narrative, history, and theology in the Gospel of John. Grand Rapids: Baker.

Bennema, C 2009. Encountering Jesus: Character studies in the Gospel of John. Milton Keynes: Paternoster.

Brodie, TL 1993. The Gospel according to John. A literary and theological commentary. New York/Oxford: Oxford University Press.

Brown, RE 1966-70. The Gospel According to John. New York: Doubleday. AB 2929A.

Brown, RE 1979. The community of the Beloved Disciple: The life, loves, and hates of an individual church in New Testament times. New York: Paulist Press.

Bruce, FF 1983. The Gospel of John. Introduction, exposition and notes. Grand Rapids: Eerdmans.

Burge, GM 1987. The anointed community: The Holy Spirit in the Johannine tradition. Grand Rapids: Eerdmans.

Coloe, ML 2001. God dwells with us: Temple symbolism in the Fourth Gospel. Collegeville: Liturgical Press.

Coloe, ML 2007. The Nazarene king: Pilate's title as the key to John's crucifixion. In: G. Van Belle (ed.), The death of Jesus in the Fourth Gospel (Leuven: Leuven University Press, BETL 200), pp 839-848.

Culpepper, RA 1983. Anatomy of the Fourth Gospel. A study in literary design. Philadelphia: Fortress.

Duke, PD 1985. Irony in the Fourth Gospel. Atlanta: John Knox.

Forster, EM 1927. Aspects of the novel. New York: Harcourt Brace.

Hanhart, K 1970. The structure of John I 35 - IV 54. Studies in John: Presented to Prof. J. N. Sevenster on the occasion of his seventieth birthday (Leiden: E. J. Brill, NovTSup), pp 22-46.

Hill, C E 1997. The identity of John's Nathanael. JSNT 67:45-61. 
Holzmeister, U 1940. Nathanael fuitne idem ac S. Bartholomaeus Apostolus? Bib 21:28-39.

Keener, CS 2003. The Gospel of John: A commentary. Peabody: Hendrickson.

Koester, CR 1990. Messianic exegesis and the call of Nathanael. JSNT 39:23-34.

Koester, CR 1995. Symbolism in the Fourth Gospel. Meaning, mystery, community. Minneapolis: Fortress.

Michaels, JR 2010. The Gospel of John. Grand Rapids: Eerdmans. NICNT.

Moule, CFD 1954. A note on 'under the fig tree' in John I.48, 50. JTS 5:210-211.

Nicklas, T 2000. Unter dem Feigenbaum: Die Rolle des Lesers im Dialog zwischen Jesus und Natanael (Joh 1:45-50). NTS 46:193-203.

Schnackenburg, R 1968-82. The Gospel according to St. John. London: Burns \& Oates.

Schnelle, U 2001. Recent views of John's Gospel. Word \& World 21:352-359.

Thatcher, T \& Moore S D (Eds.) 2008. Anatomies of Narrative Criticism: The past, present, and futures of the Fourth Gospel as literature. Atlanta: Society of Biblical Literature.

Zimmermann, R 2008. Symbolic communication between John and his reader: The garden symbolism in John 19 - 20. In: T Thatcher \& SD Moore (eds.), Anatomies of narrative criticism: The past, present, and futures of the Fourth Gospel as literature (Atlanta: Society of Biblical Literature), pp 221-235. 